\title{
COORDINATES SYSTEMS HARMONIZATION IN THE FRONTIER DISTRICTS OF THE DANUBE
}

\section{ГАРМОНИЗАЦИЯ КООРДИНАТНЫХ СИСТЕМ В ПРИГРАНИЧНЫХ РАЙОНАХ СТРАН НА ДУНАЕ}

\author{
V. Shpylevsky, Captain, PhD student, I. Krupov, ass. prof, PhD student \\ В.В. Шпилевский, капитан, аспирант, И.В. Крупов, начальник судоводительской \\ специиальности МКТФ, аспирант \\ National University “Odessa Maritime Academy”, Ukraine \\ Национальный университет «Одесская морская академия», Украина
}

\begin{abstract}
АННОТАЦІЯ
Геодезична мережа як віртуальна, так і реальна розглядається сьогодні як важлива інфраструктура подібна електричним мережам або транспортним. Кожна країна має свою національну мережу, яку будують так, щоб вона була якомога близько до поверхні геоїда иієї країни. Але геоїд не є правильною геометричною фігурою і саме тому при зустрічі геодезичних мереж на кордоні сусідніх крайн існує так званий координатний стрибок $\Delta x ; \Delta y$; $\Delta z$, який треба знайти та розподілити у виглядi поправок до геодезичних пунктів, розташованих близько кордону. Що стосується висотної референсної системи, то вихідні дані відлікових рівневих поверхонь також можуть відрізнятися на суттєві значення. Референсна система імплементована у вигляді закріплених на місиевості геодезичних пунктів. Так наприклад в Свропі використовують такі референсні системи як ETRS (European Terrestrial Reference System) $i$ ERTF (European Reference Terrestria Frame), a також EVRS (V-Vertical) i EVRF. В Украӥні використовують для планової системи координат еліпсоїд WGS 84 з визначеними параметрами та Балтійську систему висот. $B$ роботі розглянуто можливість приведення систем координат на прикордонних ділянках на річиі Дунай до загально обраної референсної системи.

Метою даного дослідження є намір розробити такий алгоритм, який дозволив би привести всі системи координат, щэо використовують придунайські крайни до гармонізованого стану, иляхом введення постійно діючих величин на кордоні иих крайн. $B$ роботі показано як можна ие реалізувати на прикладі прикордонних геодезичних мереж між Украӥною, Румунією та Болгарією.

Запропоновано використання програмного продукту DaWAT, який дозволяє автоматично трансформувати дані з вертикальної референсної системи Румунії (MN75) До Украӥнської і Болгарської (Балтійська система висот).
\end{abstract}

Ключові слова: системи координат, придунайські країни, ETRS, ERTF.

Formulation of the problem in general terms and it connection with important scientific practical tasks

The purpose of this work is to determine the basic corrections to geodetic coordinate systems at the border sections of the Danube between Romania, Bulgaria and Ukraine. Such a task has examples of solutions, but they do not take into account the characteristic features and specific characteristics of a particular site. To determine these features, it is necessary to carry out a gravimetric survey from the side of each border country to determine the parameters of the geoid and combine these parameters into one block. Then it is necessary to calculate the threshold of sensitivity (accuracy) of the coordinate system that will be taken as harmonized. After calculating the permissible coordinate accuracy in the new system (as a rule, this is the WGS $84 \mathrm{rms}$ ) for which 
7 parameters of transformation are calculated in order to move from the old system to the new one, common for all coastal countries.

\section{The paper purpose formulation}

The importance of water transport for the transport of goods and passengers using international transport corridors has increased significantly in recent years [3]. For example, in order to form a policy in the field of international transport on interstate inland waterways Gross Domestic Product (GDP), the European Union (EU) has started implementing the "NAIADES" (Navigation And Inland Waterway Action and Development in Europe) program [1], which is focused on standardizing: fleet operations, requirements for the infrastructure of water management in the European basin States. One of the important elements of the traffic management infrastructure on the GDP is the River Information System, which includes river information services (RIS).

\section{The last achievements and publications analysis, in which the solution of the problem is begun and selection of the unsolved aspects of the problem}

The relevance of this topic is to develop requirements for the GDP of Ukraine IN accordance with international documents and to build an existing system that allows you to solve both problems related to the safety of navigation on the GDP, and on its basis the problem of choosing the shortest path, optimal placement in the gateways of the queue of ships and determining the minimum travel fuel consumption, taking into account the restrictions imposed on the section of the path and taking into account optimization criteria. When following narrow corridors, please note that the positioning system must include methods and methods of radar wiring, assuming the possibility of navigation in conditions of limited visibility. Radar devices and systems can be used both on-Board and on-shore.

Studies of issues related to the harmonization of the individual tasks of the information system of waterways of Ukraine with real operating systems on the Danube other States in the submitted work was not performed.

It should be noted that this task had a state level of significance. In our country, the creation of RIS allows US to open the GDP to foreign courts under the terms of accession to the WTO.

\section{Presentation of basic research material substantiating scientific results}

Geodetic real/virtual networks can be considered today as an important infrastructure similar to power/electricity or transportation infrastructure.

Such networks provides data and information in order to establish 1D/2D/3D/4D positions expressed by coordinates in a well defined reference system (datum). A reference system it is implemented by a reference frame consisting in a set of points established in the field.

For example: ETRS (European Terrestrial Reference System) and ETRF (European Terrestrial Reference Frame); Similar EVRS (V - Vertical) and EVRF:

- In Romania ETRS89 realization includes ETRF00 epoch 2000.0 coordinates adopted for the Romanian EPN (EUREF Permanent GNSS Network) stations and stations from Romanian GNSS Permanent network (ROMPOS) (fig.1) [1].

- For the EVRS realization in Romania there are available leveling landmarks expressed as EVRF2007 or Black Sea 1975 (Constanta) normal heights.

- In Bulgaria ETRS89 realization it is based on BGS2005 including ETRF00 epoch 2005.0.

- For the EVRS realization in Bulgaria there are available leveling landmarks expressed as EVRF2007 and/or Baltic Sea - Kronstadt (1982) normal heights.

- For the ETRS realization in Ukraine it is based WGS 84 epoch 2000 coordinates.

- For the EVRS realization in Ukraine there are available leveling landmarks expressed as Baltic Sea - Kronstadt (1982) normal heights. 


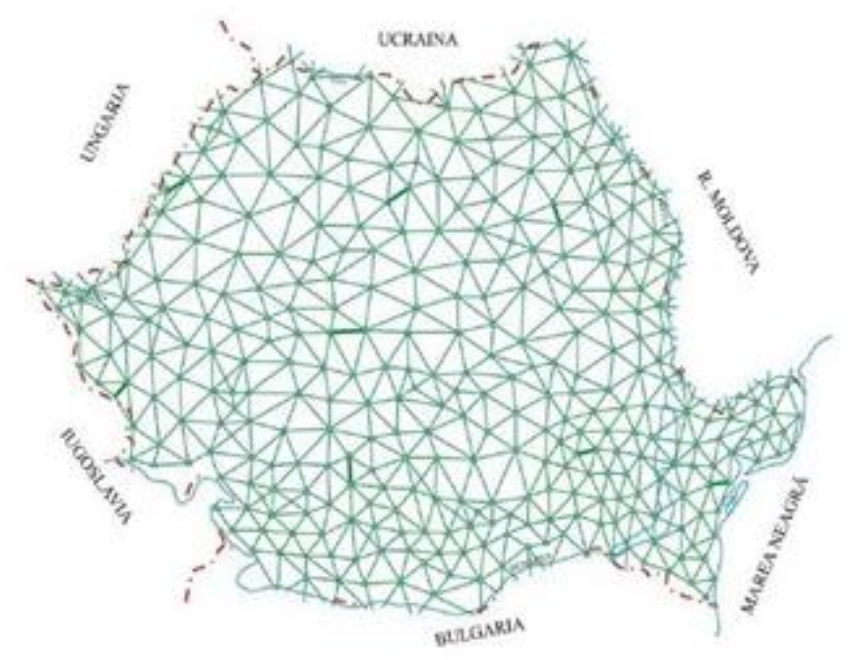

Fig.1 Geodetic network in Romania

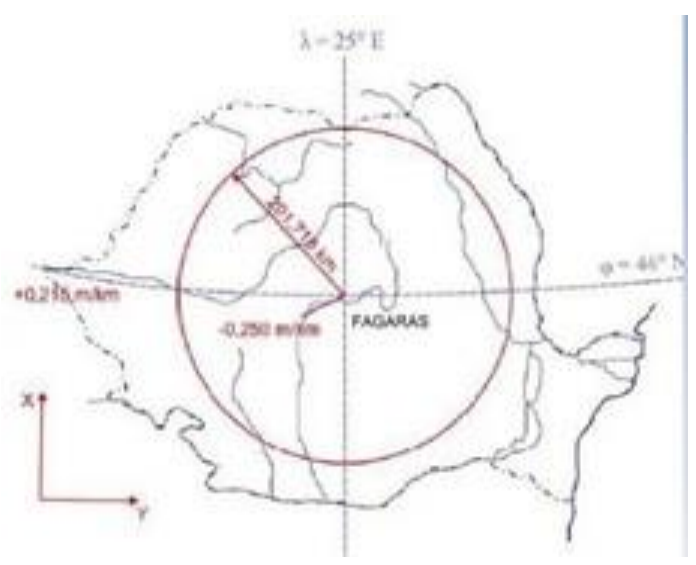

Fig.2. Ellipsoid and geoid differences

Geodetic infrastructure includes:

- Theoretical concepts (CRS - Common Reporting Standard, observations and methods, numerical computation methods, statistic indicators et al.)

- Practical "realizations": set of landmarks with known accurate coordinates = geodetic network > triangulation (2D), 2D networks / GNSS-satellite (3D), 3D networks - GNSS (fig.3) / Leveling (1D), 1D networks - Leveling Geodetic network - landmarks coordinates [2].

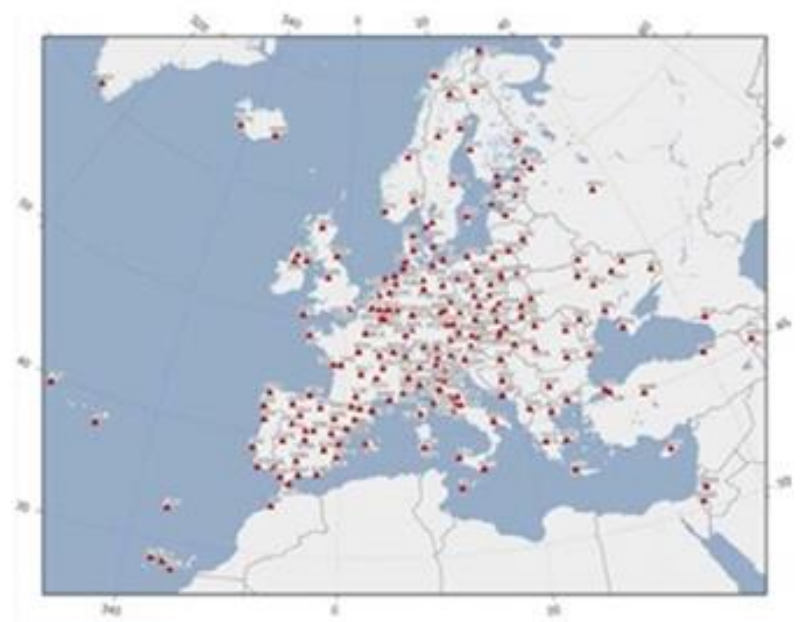

Fig.3. GNSS-satellite (3D), 3D networks - GNSS, geodetic basepoints/landmarks in

Establishment of a common geodetic system for measuring the levels of the Danube River between Ukraine - Romania and Bulgaria - harmonization of the data. DANUBE WATER - 
integrated water management project the Ukraine -Romania - Bulgaria Cross-border Cooperation Program 2012-2017 (fig.4). [3]

The project goal was to establish a common management and control system of the quality of the Danube waters under extreme conditions, caused by natural and technological disasters.

The project area included about $600 \mathrm{~km}$ on Ukraine-Romanian and Bulgarian common Danube border area, "Surveying of landmarks and development of conversion standards".

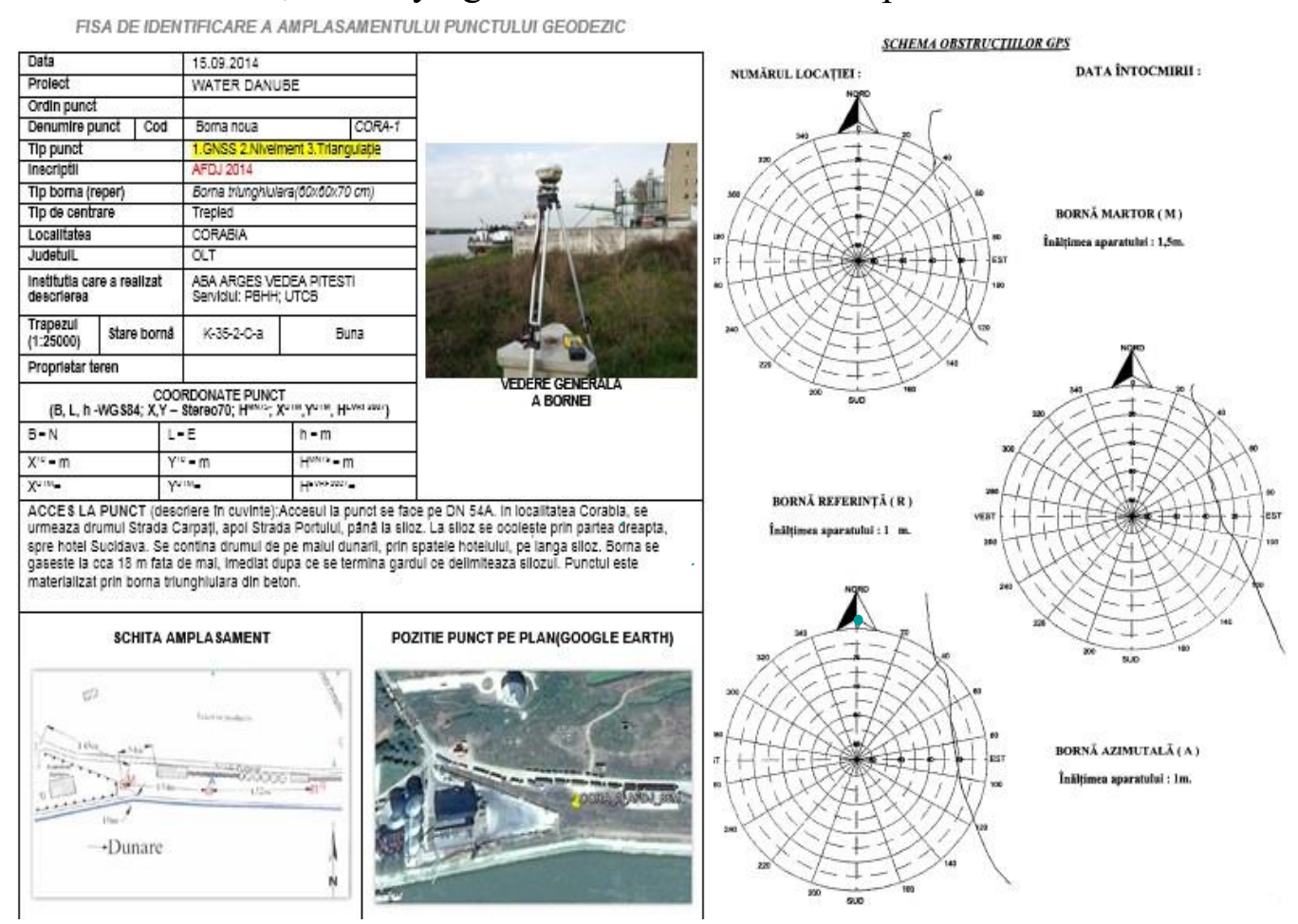

Fig.4. Project result of $\underline{U A}-R O-B G$ Cross-Border

OBJECTIVES:

Adoption of a Common geodetic system \& harmonization of data.

INSPIRE 3D/2D/1D:

- ETRS89 - implemented by ETRF00; precision: +/- $3 \mathrm{~cm} \gg$ GNSS measurements;

- 2D: UTM projection precision: $+/-2 \mathrm{~cm}>>$ GNSS measurements;

- 1D: EVRF2007 (heights) precision: $+/-1 \mathrm{~cm}>>$ leveling measurements.

Implementation of common CRS (Common Reporting Standard) by surveying and conversion/transfer Standards.

Table 1 Helmert transformation parameters (5common points)

\begin{tabular}{|c|c|c|}
\hline Transformation param. (sec) & Transformation param. $(\mathrm{sec})$ & $\begin{array}{lllr}\text { Point } & d X & d Y & d Z[m] \\
& \text { residuals } & \text { - } \\
\end{array}$ \\
\hline $0,000497 \mathrm{X}$ vector $[\mathrm{m}]$ & $0,000497 \mathrm{X}$ vector $[\mathrm{m}]$ & $\begin{array}{lllll}1,1 & 0,0153 & 0,0048 & 0,0091\end{array}$ \\
\hline $2.710724 Y \mathrm{vec}$ & $2.710724 Y v e$ & $2,2-0,0358-0,0110-0,0343$ \\
\hline$-1,064096 \mathrm{Zve}$ & $-1,064096 \mathrm{Zve}$ & $3,30,02410,0097 \quad 0,0191^{-}$ \\
\hline $0,07281956 \mathrm{X}$ angle $[\mathrm{sec}]$ & $0,3530392 X$ angle $[\mathrm{sec}]$ & $4,4-0,0154-0,0073-0,0096$ \\
\hline $0,02233018 Y$ angle [sec] & $-0,1082598 Y$ angle $[\mathrm{sec}]$ & $\begin{array}{lllll}5,5 & 0,0118 & 0,0038 & 0,0158-\end{array}$ \\
\hline $0,05557777 \mathrm{Z}$ angle [sec] & $-0,2694486 \mathrm{Z}$ angle [sec] & \\
\hline -0,0130073 Scale [ppm] & 0,0130073 Scale [ppm] & \begin{tabular}{|l}
0,0508 Max.spatial resid $[\mathrm{m}]$ \\
0,0282 Average spatial resid $[\mathrm{m}]$ \\
- \\
0,0178 Root Mean $\begin{array}{c}\text { Square res } \\
(\mathrm{RMS})[\mathrm{m}]\end{array}$
\end{tabular} \\
\hline
\end{tabular}

odetic observations along the Danube water stages: satellite (GNSS) \& terrestrial (leveling). 
Conversion \& transformation standards: existing or new developed (parameters) Transformation (1) according to EUREF standards if ETRF solution it is implemented on both sides (countries); First this hypothesis needs to be verified. Results indicated differences up to $5 \mathrm{~cm}$ between RO-ETRF00 and BG-ETRF00; and UA WGS 84 up to $25 \mathrm{~cm}$.

For transformation (1) a Helmert (7 parameters of transformation) was computed as alternative for high accuracy transformation between RO-ETRF00 and BG-ETRF00; and UA WGS 84 (fig.5).

\section{CRD differences for \\ ETRSP9 (ROB BG)}
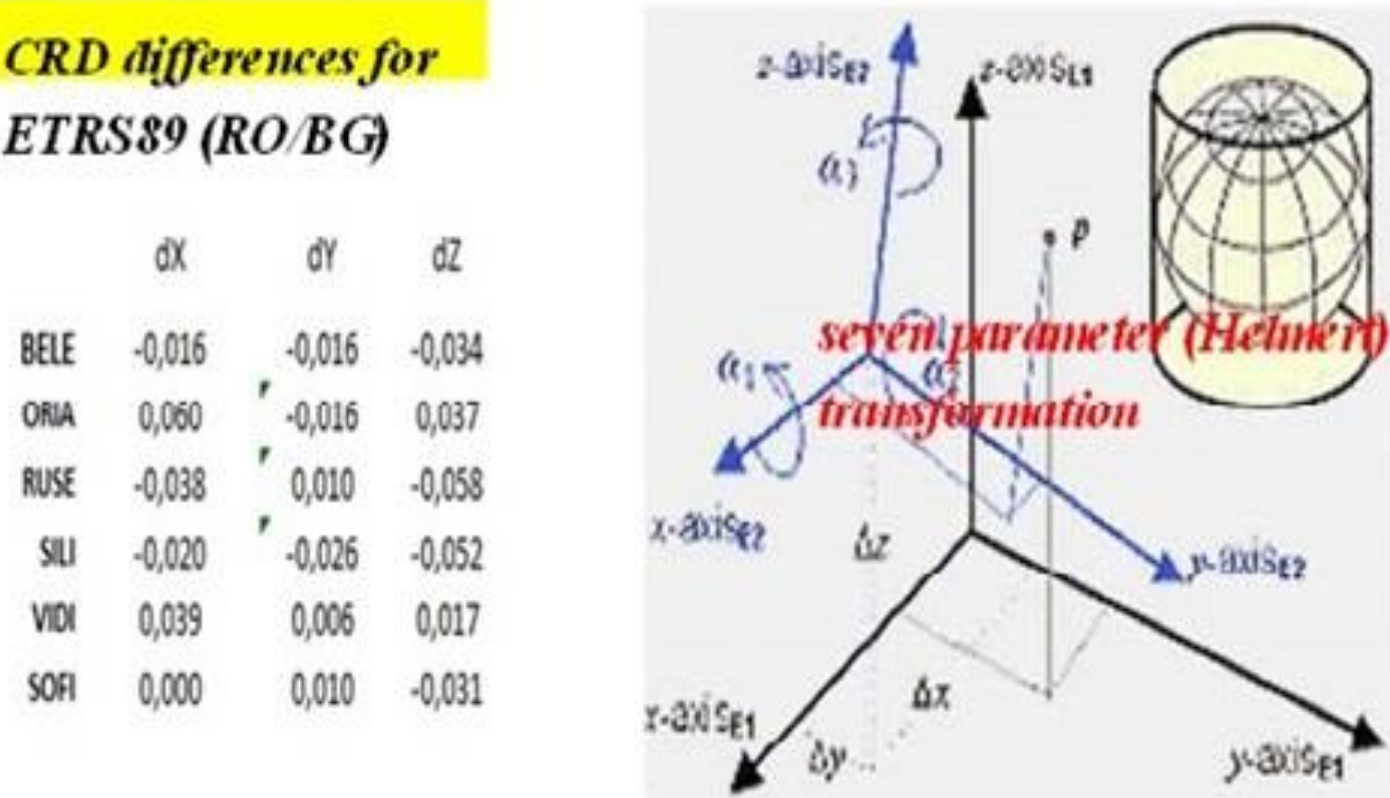

Fig.5. Result of 7 parameters of transformation at using 5 common points

For transformation (2) a standardized plane (3 parameters of transformation) was proposed according to EUREF recommendation. This was checked and works fine with official parameters and even for the landmarks from neighbour country (i.e. transformation from Baltic Sea for landmarks from RO to EVRF2007 with parameters for BG). [4]

Let start to considering some cases for transformation and implementations geodetic network in Danube border countries.

Transformation (1) according to EUREF standards if ETRF solution it is implemented on both sides (countries); First this hypothesis needs to be verified $\gg$ Results indicated differences up to $5 \mathrm{~cm}$ between RO-ETRF00 and BG-ETRF00.

A similar transformation was implemented in addition for direct transformation from RO vertical reference system (MN75) to BG vertical reference system (Baltic Sea) > DaWAT Software.

A comparison of Black Sea 1975 normal heights and EVRF2007 normal heights was performed. The results indicated a medium difference of $0.067 \mathrm{~mm}$ (EVRF2007-MN75). For BG a medium difference of $0.224 \mathrm{~m}$ (EVRF2007 - Baltic Sea).

FAIRway Danube project (2015-2020) goal to provide current and harmonized information about shallow sections, water levels and water level forecasts. Available depths will be used optimally by adapting the location of the waterway to the current riverbed conditions. In parallel, FAIRway Danube is aiming at preparing the harmonized rehabilitation of the Danube and its navigable tributaries. 
TUCEB-GEOS Research Centre to achieve the best possible link (transformation) between the height systems used in the area of interest of the project: Black Sea 1975 (RO), Baltic Sea 1982 (BG) and EVRF (UA). This link is necessary for the specific works to be carried out on the Danube for regularization, such as: water level determinations in different sections, constrain of Digital Terrain Models (DTM) in the area, vertically setting out works for rehabilitation of the Danube and its navigable tributaries, dredging et al (fig.6).

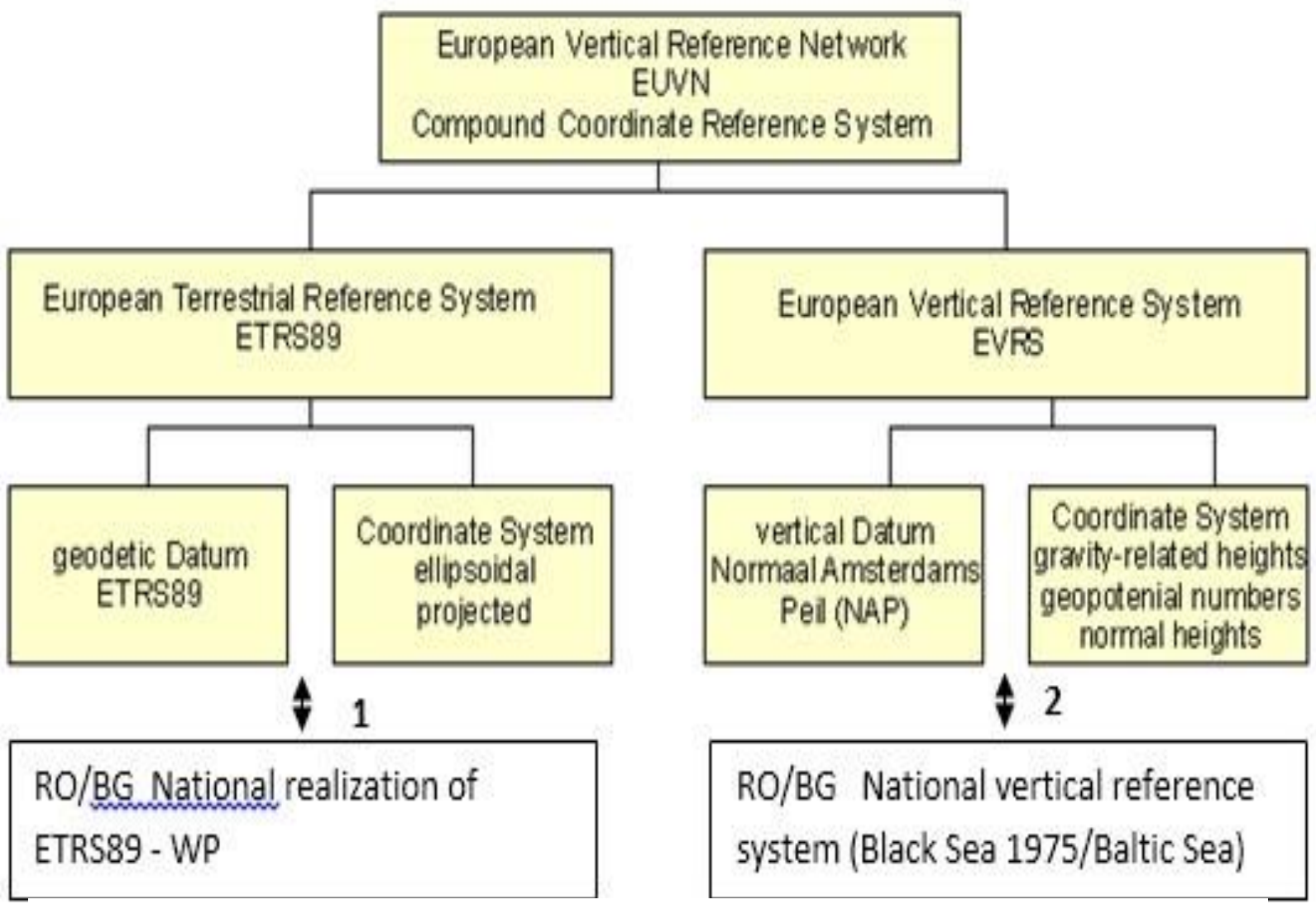

Fig.6. Scheme of geodetic network composition between RO/BG

TUCEB-GEOS proposed a methodology for determining conversion /transformation parameters between altitude reference systems used in the Danube joint sector between Ukraine Romania and Bulgaria, supplying the calculation algorithm and transformation parameters.

For transformation (3) from ellipsoidal ETRS89 heights to normal EVRF07 heights and improved transformation accuracy, a polynomial transformation was proposed (fig.9).

On the Ukrainian part of the Danube as in in the last 10 years the geodetic networks along the Danube were modernized by new landmarks, new observations including satellite (GNSS) observations and data processing, new/updated coordinates in modern reference systems.

A unified CRS should be implemented along the Danube, including navigation purposes > especially the height component can be critical if

different/less known/old reference systems are used. ETRS89/ETRF00 and EVRS/EVRF2007 are available on this area.

Transformation algorithms and software are available from/to European reference systems to national reference systems (S42 - Krasovski ellipsoid / Stereographic 1970 projection / Black Sea 1975 normal heights). Refined quasigeoid model $(+/-3 \mathrm{~cm})$ was provided by TUCEB along the UA/RO/BG Danube banks in order to be able to use "GPS leveling"(fig.7, fig.8). Geodetic network area (GRUIA / VRAV - OSTROV / Silistra. [5] 


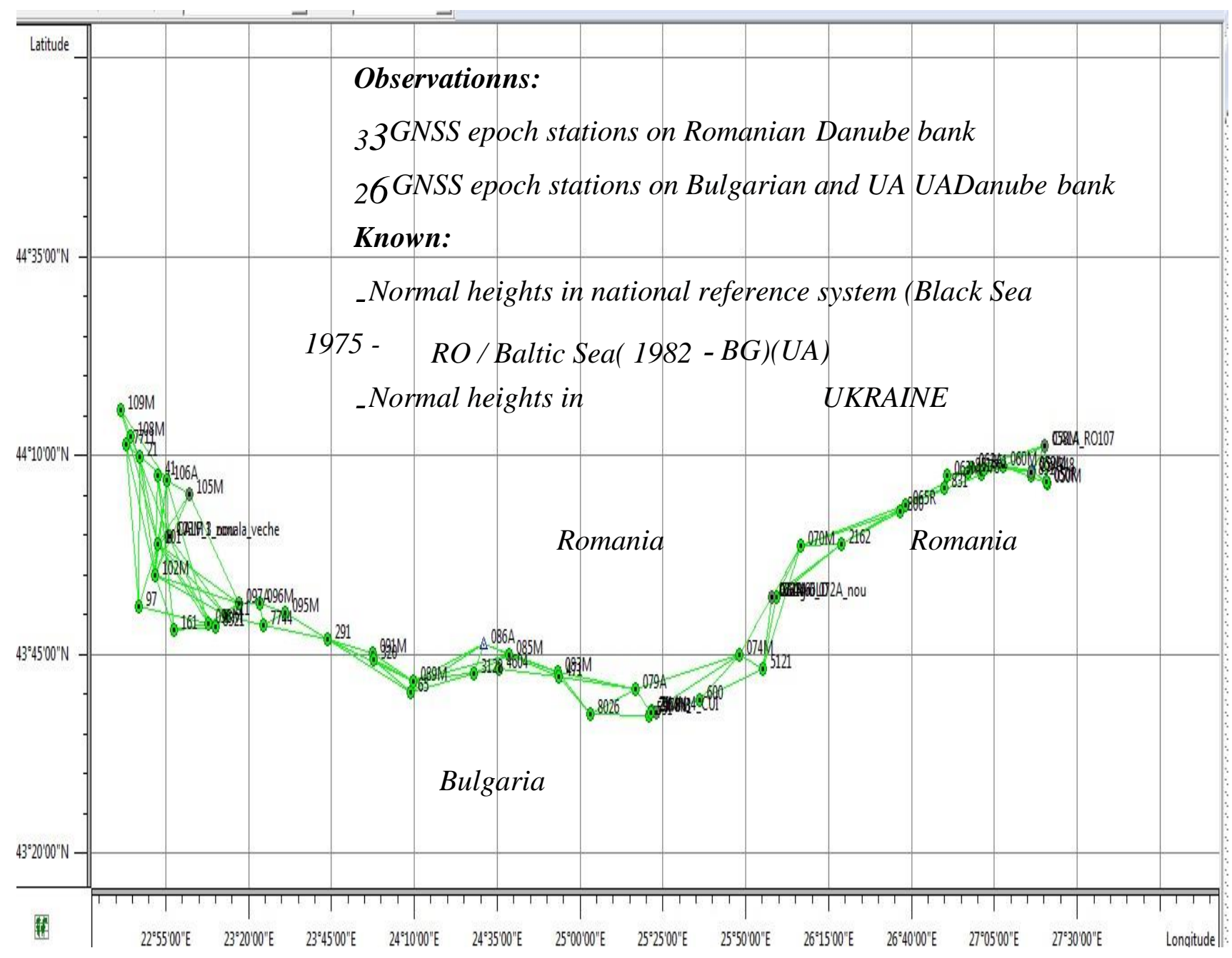

Fig.7. Points observation GNSS Epoch stations

GNSS permanent stations in the project area / EPN (European Permanent Network) stations: BUCU, COST, SOFI.

TRANSFORMATION 1 - Horizontal CRS. For the transformation from National realization of ETRS89 to ETRS89 (ETRF00), a set of seven parameters (Helmert) of transformation for each country can be provided based on GNSS data processing from a common set of GNSS permanent stations from RO and BG. From Romania EPN stations Bucharest (BUCU), Constanta (COST) and Sofia (SOFI) are also included. A third set of transformation parameters could be computed for direct transformation between National realization of ETRS89 to ETRS89 (ETRF00 epoch 2005).

TRANSFORMATION 2 - Vertical CRS. For the transformation 2 from National vertical reference system (Black Sea 1975 - MN75 for Romania and Baltic Sea 1982 for Bulgaria) to/from EVRF2007 a set of transformation parameters adopted by EUREF for each country it is available. The transformation equation it is presented below: 
Observations:

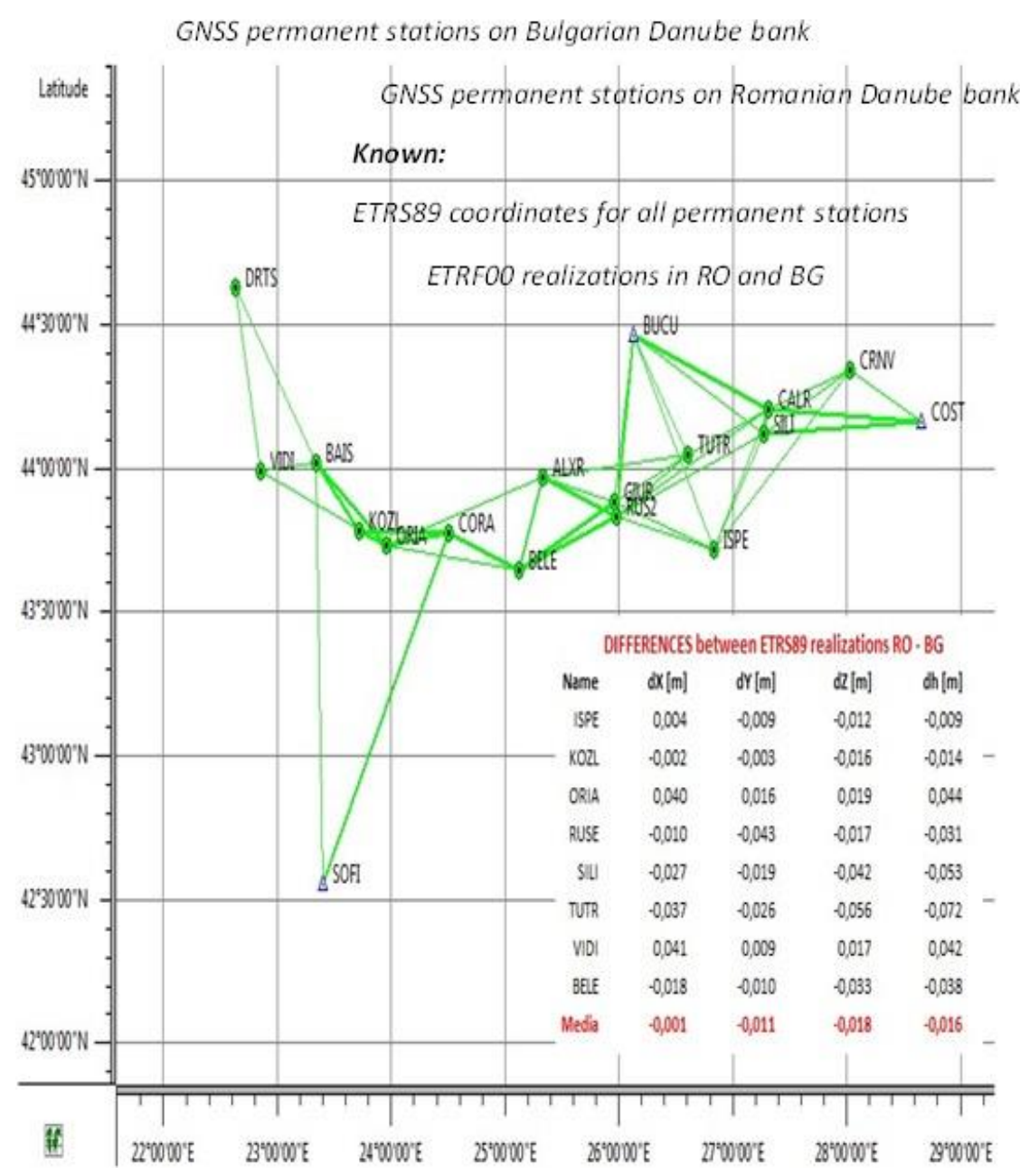

Fig.8. Scheme of GNSS permanent station $R O-B G$

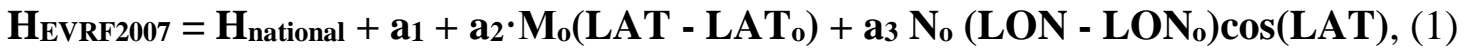
where: $\mathrm{a}_{1}, \mathrm{a}_{2}$ and $\mathrm{a}_{3}$ coefficients are known; LAT, LON - ellipsoidal coordinates;

Table 2. GNSS Permanent Stations in the project area $(R O / B G) \mathrm{LAT}_{\mathrm{o}}, \mathrm{LON}_{\mathrm{o}}$ - reference point coordinates

\begin{tabular}{|c|c|c|c|c|c|}
\hline Country & \multirow{2}{*}{ Point ID } & Point name & \multicolumn{2}{|c|}{ ETRS89-RO } & HMN \\
\cline { 4 - 5 } & & & B $(\mathrm{deg})$ & $\mathrm{L}(\mathrm{deg})$ & $75[\mathrm{~m}]$ \\
\hline RO & RO102 & Bailesti & 44,032732 & 23,352459 & 61,222 \\
\hline RO & RO107 & Calarasi & 44,187677 & 27,335867 & 15,593 \\
\hline RO & RO118 & Hodivoaia & 43,917877 & 25,779621 & 95,494 \\
\hline RO & RO142 & Turnu Magurele & 43,768856 & 24,881293 & 36,216 \\
\hline RO & RO143 & Vinju Mare & 44,432561 & 22,864746 & 94,044 \\
\hline RO & 9 & Negru Voda (ROBG) & 43,788889 & 28,156944 & 161,821 \\
\hline RO & 23 & Calafat & 43,996667 & 22,932500 & 69,919 \\
\hline RO & 19 & Giurgiu & 43,895278 & 25,959444 & 20,634 \\
\hline RO & 20 & Turnu Magurele & 43,751111 & 24,876944 & 29,931 \\
\hline RO & 22 & Calarasi & 44,197778 & 27,354722 & 18,750 \\
\hline
\end{tabular}

All the landmarks observed by precise levelling can be determined in the national vertical system and after, by transformation eq.(1), in the EVRF2007. As examples there are results in Tab.1 
(landmarks from Romania) for EUVN stations situated in five areas (Calafat, Turnu Magurele, Giurgiu, Calarasi and Negru Voda). Three of these areas were directly connected by precise levelling (Calafat, Giurgiu and Ostrov)[6].

As examples there are results in Table1 (landmarks from Romania) for EUVN stations situated in five areas (Calafat, Turnu Magurele, Giurgiu, Calarasi and Negru Voda). Three of these areas were directly connected by precise levelling (Calafat, Giurgiu and Ostrov).

Table 3. A comparison of Black Sea 1975 normal heights and EVRF2007

\begin{tabular}{|l|l|l|l|l|l|}
\hline \multirow{2}{*}{ Point ID } & ETRS89-RO & MN75 & $\begin{array}{l}\text { EVRF } \\
\text { [m] }\end{array}$ & $\begin{array}{l}\text { Diff. } \\
{[\mathrm{m}]}\end{array}$ \\
\cline { 2 - 3 } & $\mathrm{B}[\mathrm{deg}]$ & $\mathrm{L}[\mathrm{deg}]$ & $607[\mathrm{~m}]$ & $-0,063$ \\
\hline RO102 & 44,03273248 & 23,352458 & 61,222 & 61,285 & $-0,075$ \\
\hline RO107 & 44,18767743 & 27,335867 & 15,593 & 15,668 & $-0,071$ \\
\hline RO142 & 43,76885594 & 24,881292 & 36,216 & 36,284 & $-0,068$ \\
\hline RO143 & 44,43256133 & 22,864746 & 94,044 & 94,104 & $-0,060$ \\
\hline 9 & 43,788889 & 28,156944 & 161,821 & 161,899 & $-0,078$ \\
\hline 23 & 43,996667 & 22,932500 & 69,919 & 69,981 & $-0,062$ \\
\hline 19 & 43,895278 & 25,959444 & 20,634 & 20,705 & $-0,071$ \\
\hline 20 & 43,751111 & 24,876944 & 29,931 & 29,999 & $-0,068$ \\
\hline 22 & 44,197778 & 27,354722 & 18,750 & 18,825 & $-0,075$ \\
\hline
\end{tabular}

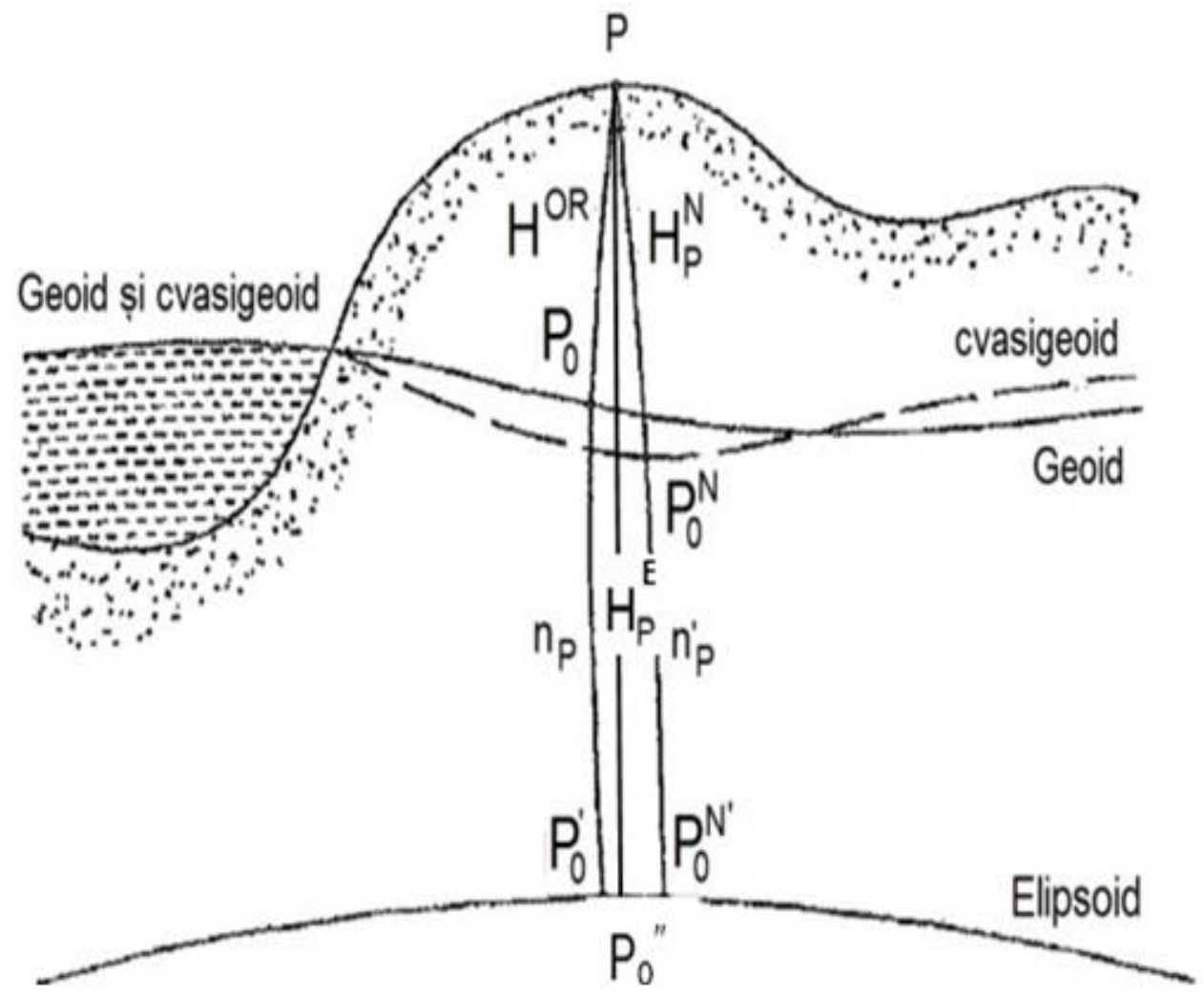

Fig.9. Scheme of transformation from ellipsoidal heights to normal heights The results indicated a medium difference of $67 \mathrm{~mm}$ (EVRF2007MN75) 
A similar comparison indicate a difference of $225 \mathrm{~mm}$ for Bulgaria (EVRF2007 - Baltic Sea 1982). Main problem: to be able to obtain (normal) heights. TRANSFORMATION 3 - Ellipsoidal to normal height with $+/-(1 \ldots 3) \mathrm{cm}$ accuracy for the project area where classical precise leveling observations are impossible or difficult to be realized (Table 2).

Solution: to use GNSS observations (ellipsoidal) heights combined with a local accurate (quasi)geoid model

Algorithm: to compute (quasi)geoid undulations n'p for the geodetic network points

$$
\mathrm{n}^{\prime} \mathrm{p}=\mathrm{H}_{\mathrm{p}} \mathrm{E}-\mathrm{H}_{\mathrm{p}} \mathrm{N} \text {, }
$$

where: $\mathrm{p}$ - points with known ellipsoidal and normal heights to establish a local model of these quantities for the project area.

For fig. 9 we can say that:

$$
\text { n'p }=f(x, y),
$$

where: $(\mathrm{x}, \mathrm{y})$ - horizontal coordinates where we are use the local (quasi) geoid model for normal of Height sytems height determinations from GNSS ellipsoidal heights $\mathrm{N}=\mathrm{H}_{\mathrm{i}} \mathrm{E}-\mathrm{n}$ 'i i - points observed by GNSS (ellipsoidal - $\mathrm{H}_{\mathrm{p}} \mathrm{E}$, normal - $\mathrm{H}_{\mathrm{p}} \mathrm{N}$, ortometric $-\mathrm{H}_{\mathrm{p}} \mathrm{OR}$ ), $\mathrm{H}_{\mathrm{i}}$.

\section{FOR TRANSFORMATION 1}

A set of 7 parameters (Helmert) of transformation, in order to be able to pass from RO ETRS89 realization to BG ETRS89 realization or opposite (if necessary).

\section{FOR TRANSFORMATION 2:}

A set of 3 parameters of transformation, in order to convert from national vertical reference systems to

$$
\begin{aligned}
& \text { EVRF07H }\left(\text { EVRF2007) }=\mathrm{H}(\mathrm{MN} 75)+\mathrm{a}_{1}+\right. \\
& +\mathrm{a}_{2} \mathrm{M} 0\left(\mathrm{~B}-\mathrm{B}_{0}\right)+\mathrm{a}_{3} \mathrm{~N}_{0}\left(\mathrm{~L}-\mathrm{L}_{0}\right) \cos (\mathrm{B})
\end{aligned}
$$

\section{FOR TRANSFORMATION 3:}

A set of 10 parameters for a polynomial transformation, in order to transform from ETRS89 ellipsoidal heights to EVRF07 normal heights:

$$
\begin{gathered}
n^{\prime} \mathrm{i}(\mathrm{x}, \mathrm{y})=\mathrm{p}_{1}+\mathrm{p}_{2} \mathrm{x}+\mathrm{p}_{3} \mathrm{y}+\mathrm{p}_{4} \mathrm{x}_{2}+\mathrm{p}_{5} \mathrm{xy}+ \\
\left.+\mathrm{p}_{6} \mathrm{y}_{2}+\mathrm{p}_{7} \mathrm{x}_{3}+\mathrm{p}_{8} \mathrm{x}_{2} \mathrm{y}+\mathrm{p}_{9} \mathrm{xy}_{2}+\mathrm{p}_{10} \mathrm{y}_{3}\right) \\
\mathrm{H}_{\mathrm{i}} \mathrm{N}=\mathrm{H}_{\mathrm{i}} \mathrm{E}-\mathrm{n} \mathrm{n}^{\prime} \mathrm{i}, \quad \mathrm{i}-\text { points observed by GNSS. }
\end{gathered}
$$

Observatyion of transformation 3 it is the most important if we know that the access by (precise) geometric leveling to the project area it is very difficult and now an alternative of GNSS leveling was implemented for accuracies of $3 \mathrm{~cm}$. Software implementing the coordinate transformations for the project area DaRAT software was realized by Research. Software implementing the coordinate transformations for the project area.

Software window with transformation from RO national to EVRF07 normal height. Software implementing the coordinate transformations for the project area. Software window with transformation from ellipsoidal ETRS89 to EVRF07 normal height. Software implementing the coordinate transformations for the project area. Software window with transformation from geodetic (ellipsoidal) coordinates to UTM plane coordinates.

\section{Conclusions}

In the Ukraine - Romanian border part of the Danube as in other similar countries in the last 10 years the geodetic networks along the Danube were modernized by new landmarks, new observations including satellite (GNSS) observations and data processing, new/updated coordinates in modern 
reference systems. A unified CRS should be implemented along the Danube, including navigation purposes > especially the height component can be critical if different/less known/old ref. systems are used.

ETRS89/ETRF00 and EVRS/EVRF2007 are available on this area. Transformation algorithms and software are available from/to European reference systems to national reference systems (S42 Krasovski ellipsoid / Stereographic 1970 projection / Black Sea 1975 normal heights). Refined quasigeoid model $(+/-3 \mathrm{~cm})$ was provided by TUCEB along the RO/BG Danube banks in order to be able to use "GPS leveling" [7].

\section{The Applications area of the DanubeGeodetic infrastructure includes:}

- Danube navigation improvement > more accurate positioning based on geodetic network;

- Water level measurements in a unified reference system;

- "Zero" level new (re)established at hydrometric stations;

- Posibility to perform "GPS leveling" in areas with difficult access;

- Navigation maps/charts to be upgraded more easy;

- Maintenance works along the Danube aided by new geodetic network: New DTM's, profiles, bathymetry;

- More accurate risk/hazard maps.

Other applications: cadaster, railway/highway transport closed to the Danube.

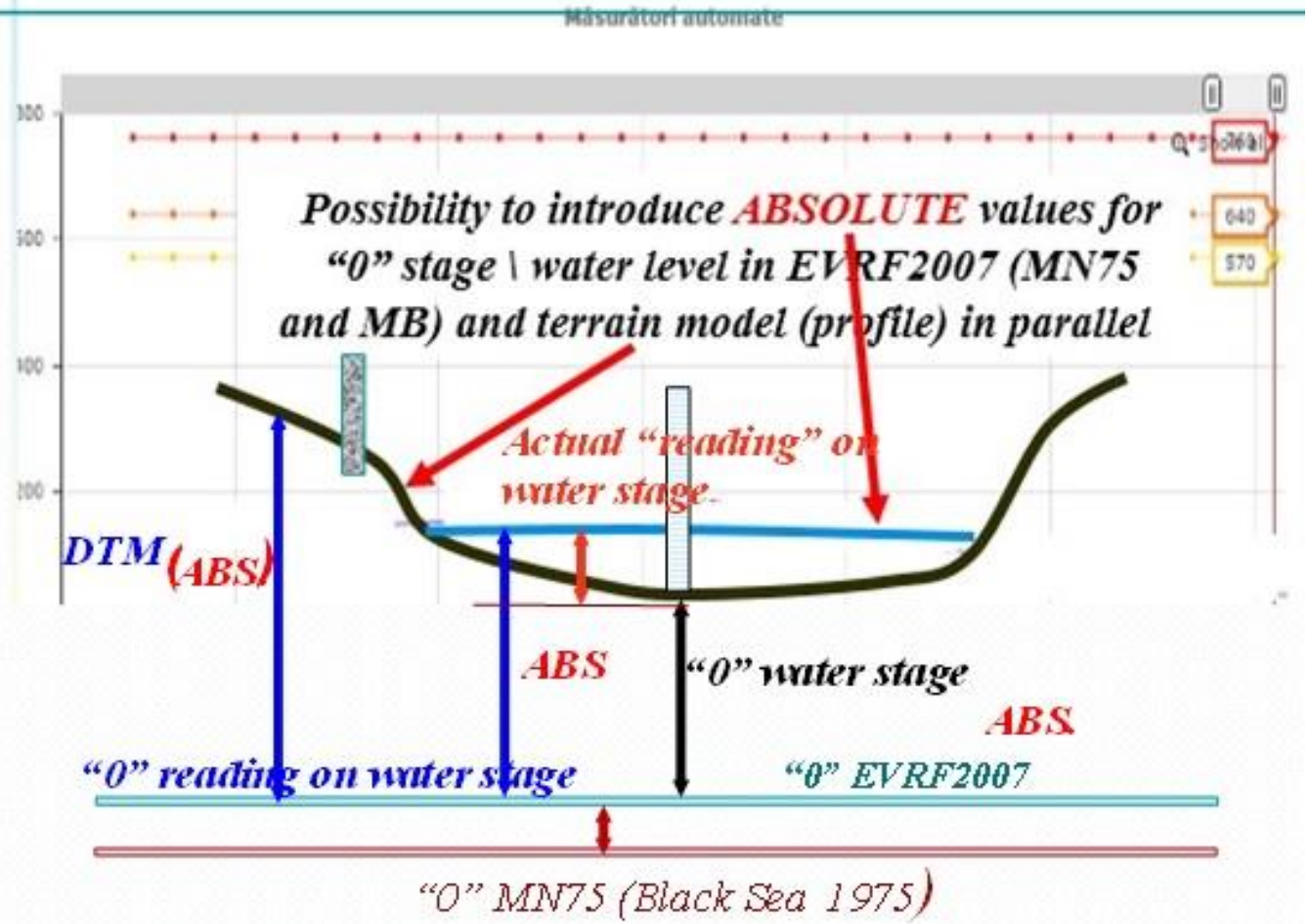

Fig.10. Scheme of height water level obtain

\section{Proposals \& Conclusions}

1. Based on a theoretical and practical UA/RO/BG experience concerning old/new CRS's along the common part of the Danube, as a good practice, similar studies should be performed in other Danube sectors. RO/SR sector and RO/UA some sectors stil to continue communication work.

2. As a consequence, EVRS/EVRF (2007) can be implemented and transformation to/from other CRS's can be available.

3. If relative values for the water levels are a common practice in NAVIGATION: we propose as in paralel, ABSOLUTE values for the water levels to be implemented.

Advantages: i.e. more straight connection of Danube water level with DTM including dams/bridges around the area, faster floods modelling and scenarios. Possibility to introduce AND ABSOLUTE values for "0" stage in EVRF2007 at all reference systems: MN75 and MB. 


\section{REFERENCES}

1. Bulgarian National Committee of Geodesy and Geophysics, National Report on Geodetical and Geophysical Activities in Bulgaria 2007 - 2011, Prepared for the XXVth IUGG General Assembly, Melbourne - Australia, 28 June - 7 July 2011.

2. Romanian National Committee of Geodesy and Geophysics, National Report on Geodetic and Geophysical Activities 2007-2010, XXVth IUGG General Assembly, Melbourne, 28 June -7 July 2011.

3. Implementation Plan of the Activity 6 - on WATER project (MIS 161) funded under Romania-Bulgaria - Ukraine cross border Cooperation Programme 2012-2017.

4. Technical Specifications for the implementation of the Activity 6 - on WATER project (MIS 161) funded under Romania-Bulgaria cross border Cooperation.

5. I.I. Gladkykh. - UA National UkrRIS Status.- www.gisforumdanube.org/disc19-// DISC 19, Tom.1, 17.12.2019 / - P. 9-21. - Timisoare, Romania.

6. Avramiuc N., Dragomir P., Rus T., Algorithm for direct and inverse coordinate transformation between ETRS89 CRS and S-42 CRS, International.

7. Dragomir P., Rus T., Avramiuc N., Dumitru P., EVRF2007 as Realization of the European Vertical Reference System (EVRS) in Romania, International Symposium GeoCAD08, Alba Iulia, Romania, 09-10 May 2010.

8. http://earth-info.nga.

9. V. Dvoretsky, The effect of inaccuracies of the auxiliary sensors in the course of data processing of multibeam survey. / В.А. Дворецкий, И.Э. Изаак // Вісник ОНМУ. Вып.№4(57). - Одеса: Видавництво ОНМУ, 2018. - С.160 - 166. 